DOI: 10.19195/0137-1150.167.27

\author{
ANNA PASZKIEWICZ
}

Uniwersytet Wrocławski, Polska

\title{
Suicidia w twórczości Gajto Gazdanowa
}

Inteligencję pierwszej fali emigracji rosyjskiej wyróżnia szczególne egzystencjalne ukierunkowanie, koncentracja na wyjaśnianiu kluczowych ontologicznych opozycji — bytu i niebytu, życia i śmierci. Zwłaszcza filozofowie Nikołaj Bierdiajew i Lew Szestow roztrząsali te kwestie. Natomiast literatów zarówno starszej (między innymi Iwana Bunina, Aleksandra Kuprina, Iwana Szmielowa, Borysa Zajcewa, Dymitra Miereżkowskiego), jak i młodej generacji, debiutującej dopiero na wygnaniu, która podczas rewolucji i wojny domowej wyjątkowo często stykała się ze śmiercią, temat ten przerażał, a zarazem fascynował. Poeta Borys Popławski - jeden z czołowych reprezentantów tak zwanego niedostrzeżonego pokolenia, zwany rosyjskim Rimbaudem, i tak jak autor Pijanego statku młodo zmarły, wskazywał w swoim szkicu $O$ мистической атмосфере молодой литературы в эмиграиии (1930) na otaczającą wygnańców z Rosji wprost zabójczą dla nich atmosferę agonii i wyczekiwania na zagładę: „Христос агонизирует от начала и до конца мира. Поэтому атмосфера агонии единственная приличная атмосфера на земле [...] Как жить? - Погибать [...] Эмиграция - идеальная обстановка для этого"1. Z kolei thumacz Iwan Tchorżewski w słynnym wierszu Легкой жизни я просил у Бога zalecał modlić się nie o łatwe życie, lecz o lekką śmierć. Wszyscy ci twórcy znaleźli azyl we Francji, większość z nich miała tam spędzić całe życie, lecz czuli się na paryskim bruku obco, niczym obywatele drugiego sortu, zżerani przez tęsknotę za utraconą ojczyzną, samotność i biedę.

Zrozumiałe więc, że emigrantom bliska była w ich literackiej twórczości problematyka tanatologiczna. Widać to zwłaszcza u Gajto Gazdanowa. Już Dienes Laslo, pierwszy biograf tego pisarza, zauważył, że śmierć jest niemal obsesją autora Wieczoru u Claire. Wciąż pisze on o umieraniu, samobójstwach bądź za-

${ }^{1}$ Б. Поплавский, О мистической атмосфере молодой литературы в эмигращии, „Числа" 1930, nr 2/3, s. 309. 
bójstwach, a nierzadko o wpływie świadomości, że śmierć jest przeznaczeniem każdego człowieka, na psychikę ludzką ${ }^{2}$.

Badacze spuścizny Gajto Gazdanowa niejednokrotnie wskazywali na nieustanną obecność motywu śmierci w jego utworach ${ }^{3}$. Dostrzegli, że w ich strukturze śmierć stanowi podstawę fabuły. Bywa również kategorią estetyczną, etyczną bądź metafizyczną, zakorzenioną w świadomości człowieka, a zatem - egzystencjalną ${ }^{4}$. Pomimo zaawansowanego stanu badań nad motywiką tanatalogiczną w spuściźnie literackiej Gajto Gazdanowa potencjał interpretacyjny związanej z nią problematyki wciąż jest znaczny. Sygnalizowane są nowe pola badawcze, które ta problematyka wytycza ${ }^{5}$. Niektóre jej aspekty wymagają wszakże sprecyzowania i uporządkowania. Jednym z nich jest, jak sądzę, problem suicydiów.

Wzmianki o śmierci samobójczej lub jej opisy mają w powieściach Gazdanowa nader zróżnicowane motywacje. Samobójstwo może być na przykład ucieczką przed absurdem egzystencjalnym - jak w powieści Wieczór u Claire (Вечеp у Клэр, 1929) desperacki czyn młodzieńca, który się zastrzelił, przekonany argumentacją wujka narratora, że życie nie ma sensu. W powieści Powrót Buddy (Возвращение Будды, 1949) о samobójstwie myśli emigrant Paweł Szczerbakow, który znalazł się na dnie życia i musi żebrać (zresztą i tak umrze śmiercią nienaturalną, zamordowany po otrzymaniu spadku). W swojej celi wiesza się ogrodnik Paul Kleman, skazany na dwadzieścia lat więzienia za zabójstwo, którego nie popełnił — postać z powieści Ewelina i jej przyjaciele (Эвелина и её друзья, 1968). To samo robi Fiedorczenko z Nocnych dróg (Ночные дороги, 1941). Samobójczą śmiercią ginie także cierpiący na manię prześladowczą inny bohater tej powieściWasiliew. Wskutek zdrady miłosnej życie odbiera sobie londyńska kochanka Wolfa w Widmie Aleksandra Wolfa (Призрак Александра Вольфа, 1947). W tym samym dziele przyczyną aktu suicydalnego jest również bankructwo — na śmierć decyduje się para wiekowych małżonków, ponieważ ich akcje straciły wartość.

${ }^{2}$ L. Dienes, Russian Literature in Exile. The Life and Work of Gaito Gazdanov, München 1982, s. 187-193.

${ }^{3}$ Zob. np. М. Н. Шабузова, Тема смерти в ранних рассказах Газданова, [w:] Возвращение Гайто Газданова, Науч. конф. посвящ. 95-летию со дня рождения (4-5 дек. 1998), wуb. М. А. Васильева, Москва 2000, s. 164-168; А. Ю. Закуренко, Три лика смерти в романах Газданова, „Русская словесность” 2002, nr 4, s. 5-15; М. В. Мокрова, Танатология Г. Газданова и Б. Поплавского, [w:] Актуальные проблемы общественных наук и творческих професий (философия, история, социология, культура, искусство, религия), red. В. К. Крючек, Волгоград 2005, s. 82-86.

${ }^{4}$ Zob. Ю. В. Матвеева, Экзистенцииальное начало в творчестве Гайто Газданова, „Дарьял - литературно-художественный и общественно-политический журнал” 2001, nr 2, s. 151.

${ }^{5}$ Roman Krasilnikow uważa na przykład, iż do analizy motywów tanatologicznych w twórczości G. Gazdanowa niezbędna jest znajomość buddyzmu. Zob. idem, Танатологические мотивы в художественной литературе (Введение в литературоведческую танатологию), Москва 2015, s. 116. 
W Widmie Aleksandra Wolfa i Przebudzeniи (Пробуждение, 1965) mają również miejsce zagadkowe samobójstwa. W pierwszym z utworów młoda nauczycielka gimnazjum nagle odbiera sobie życie — nie wiadomo z jakiego powodu. W drugim - fragment ogłoszenia prasowego informuje o topielicy, której imię i przyczyna śmierci pozostają nieznane.

Warto wspomnieć jeszcze o rozłące jako o metaforycznym samobójstwie po utracie ukochanej w Powrocie Buddy. Nieudane samobójstwo w Locie (Полёm, 1939) to z kolei symbol niespełnionego życia; zresztą rana — skutek tej próby samobójczej - nie okazała się śmiertelna. Zamiar młodziutkiej Jeanine, by się otruć tabletkami nasennymi, udaremniają w powieści Pielgrzymi (Пилигримы, 1953) Andre i jego syn Robert, zakochany w tej dziewczynie ${ }^{6}$.

Akt suicydalny pełni u Gazdanowa funkcję motywu kształtującego fabułę. Natomiast jego rola we wczesnych utworach pisarza jest bardziej złożona. W opowiadaniu Wielki mиzyk (Великий музыкант, 1931) uwagę narratora przyciąga ciało samobójcy:

Я подошёл ближе и спросил у полицейского, в чём дело. — Самоубийца — коротко ответил он. Я приблизился к скамейке и увидел лежавшего на ней человека со свисающей вниз головой, раскинутыми руками, пальцы которых были сжаты в кулаки, и ногами, показавшимися мне необычайно длинными. Это был алжирец, одетый со специальным и своеобразным шиком, с которым одеваются парижские сутенеры и который тогда, в то утро, был особенно оскорбителен ${ }^{7}$.

Następujący niewiele później szczegółowy opis garderoby świadczy o fascynacji widokiem trupa. Sam bohater zainteresowanie to określa mianem „nieświadomej, bezpłodnej ciekawości” („бессознательное, бесплодное любопытство") ${ }^{8}$.

Podatność na akty suicydalne jest pochodną wspomnianej już atmosfery, która ciążyła nad rosyjską emigracją pod koniec lat dwudziestych i trzydziestych XX wieku. W ówczesnej epoce społecznego, moralnego i metafizycznego kryzysu samobójstwo stało się sposobem ostatecznego rozstrzygnięcia egzystencjalnych dylematów ${ }^{9}$. Samobójca z opowiadania Wielki muzyk jest wprawdzie Algierczykiem, ale przedstawiona tam historia rozgrywa się w środowisku rosyjskiej diaspory.

Nikołaj Bierdiajew tak charakteryzował ów destrukcyjny fenomen w szkicu psychologicznym O samobójstwie (1931):

Problem samobójstwa jest jednym z najbardziej niespokojnych i bolesnych wśród rosyjskich emigrantów. Bardzo wielu Rosjan kończy życie samobójstwem. Utrata sensu życia,

${ }^{6}$ Por. Е. Н. Проскурина, Танатологический сюжетно-мотивный комплекс в романно прозе Г. Газданова, „Критика и семиотика” 2013, nr 2, s. 213.

${ }^{7}$ Г. Газданов, Великий музыкант, [w:] idem, Собрание сочинений в трёх томах. Рассказы. На франиузской земле, t. 3, Москва 1996, s. 192.

${ }^{8}$ Ibidem.

9 О.Р. Демидова, Самоубийство как символический акт, [w:] еadem, Метаморфозы в изгнании. Литературный быт русского зарубежья, Санкт-Петерсбург 2003, s. 123-124. 
oderwanie od ojczyzny, krach nadziei, samotność, nędza, choroby, nagła zmiana warunków socjalnych, kiedy ktoś, kto należał do klasy wyższej, staje się zwykłym robotnikiem, niewiara w możliwość polepszenia warunków życia w przyszłości — wszystko to bardzo sprzyja epidemii samobójstw [...]. Przyczyną skłonności samobójczych na emigracji są nie tylko potrzeby materialne, brak zabezpieczenia na przyszłość, choroby, ale jeszcze bardziej przerażenie, że już zawsze, do końca swoich dni, trzeba będzie żyć w obcym, chłodnym świecie, i że życie takie nie ma ani sensu ani celu ${ }^{10}$.

Losy emigrantów z Wielkiego muzyka są egzemplifikacją przytoczonych spostrzeżeń. Algierska narodowość samobójcy jeszcze mocniej uwypukla jego osamotnienie w obcym środowisku.

Bierdiajew rozpatrywał fenomen samobójstwa w dwóch kontekstach: chrześcijańskim i sekularnym, czyli w odniesieniu do Boga i do społeczeństwa. W obydwu przypadkach jednostka ludzka jest częścią całości (częścią Boga i częścią jednego „ciała społecznego”), co każe widzieć w samobójstwie niepojęty, porównywalny z zabójstwem ${ }^{11}$, akt. Rozpowszechnienie suicydalnych nastrojów na emigracji stwierdzał Bierdiajew — skutkuje „osłabieniem i rozkładem siły rosyjskiej”. Badacz dowodzi też, że „Rosjanie nie wytrzymują presji historycznego doświadczenia”, nie są gotowi „nieść w sobie Rosji i ponosić odpowiedzialności za losy Cerkwi rosyjskiej”. Zatem samobójstwo jest zbrodnią przeciw społeczeństwu, Rosji i prawosławiu $^{12}$.

Kolejny utwór Gazdanowa, w którym występuje akt suicydalny, będący swego rodzaju polemiką z rozważaniami Bierdiajewa o samobójstwie, to opowiadanie Żelazny lord (Железный лорд, 1934), wyraźne zainspirowane twórczością Prousta. Dzięki zapachowi róż na paryskiej Halles jego akcja przenosi się ze stolicy Francji do Rosji, przypominając narratorowi dawno minione czasy dzieciństwa oraz samobójstwo, z jakim się wtedy zetknął. Nie poznałby przyczyny śmierci Wasilija Nikołajewicza, gdyby nie wpadł mu w ręce kilka lat później jego list. Mowa w nim o szczęśliwym pobycie na Syberii młodego małżeństwa i późniejszej zdradzie mężczyzny, czego konsekwencją staje się choroba weneryczna i rozkład pożycia małżeńskiego. Przyszły samobójca wyznaje ze skruchą:

Так печально и глупо [...] звучат теперь научные термины о полигамии и сексуальных аффектах — на кой чёрт мне все эти объяснения и прочая ерунда, когда я исковеркал три жизни, и только в одном случае у меня есть возможность поступить так, как должен поступить порядочный человек; а в других это непоправимо ${ }^{13}$.

Samobójstwo jako odwet za zmarnowane życie trzech osób traktowane jest tutaj wyrozumiale. Dodajmy, że Gazdanowa mniej interesuje sam przebieg tego aktu niż jego przyczyny. Najczęściej mowa o tym wydarzeniu post factum, gdyż

${ }^{10}$ Н. А. Бердяев, О самоубийстве (Психологический этюд), [w:] А. Н. Моховиков, Суииидология. Прошлое и настоящее. Проблема самоубийства в трудах философов, соииологов, психотерапевтов и в художественных текстах, Москва 2013, s. 89-90. Tłuт. А. Р.

11 О. Р. Демидова, Самоубийство как символический акт, s. 124-125.

12 Н. А. Бердяев, О самоубийстве..., s. 90.

${ }^{13}$ Г. Газданов, Железный лорд, [w:] idem, Собрание сочинений в трёх томах, s. 356. 
moment śmierci u analizowanego tu autora to coś głęboko intymnego. We wspomnianym opowiadaniu nawet stary pies, tytułowy Żelazny Lord, kończy żywot samotnie (co skądinąd jest zgodne z naturą zwierząt).

Przyszły samobójca jest bardzo zainteresowany swoim wyglądem po śmierci. Nie chce przerażać bliskich, a zamierza rzucić się pod pociąg. W zapiskach Wasilija Nikołaewicza czytamy: „Я не знаю, как они положат меня в гроб, было бы хорошо, если бы можно было скрыть, что моё тело разрезано на куски колёсами поезда. Мне бы не хотелось, чтобы Леля видела меня разрезанным"14. Życzenie zostaje spełnione dzięki różom, których sterty zakryły poszarpane ciało:

и только разрезанное тело, на котором лежало такое количество роз затем, чтобы они закрыли страшную полосу, отделившую голову от туловища, пронесли потом медленно и торжественно - сперва в дымную и высокую церковь, потом на далёкое кладбище, заставленное крестами 15 .

Nieboszczyk nie został ekskomunikowany, co byłoby zgodne z zasadami chrześcijaństwa i prawosławnej Cerkwii. W pamięci - ważnej kategorii w prozie Gazdanowa ${ }^{16}$ — ostały się głównie róże, które łączą samobójstwo sprzed lat z emigracyjną, napawającą bohatera obrzydzeniem codziennością: „розы на Halles, со сверкающими каплями воды на лепестках — в липком и отвратительном парижском тумане, пропитанном лёгким и печальным запахом гнили" $" 17$.

Żelazny lord Gazdanowa przynosi całkiem odmienne spojrzenie na akt suicydalny niż to, które zaproponował Bierdiajew. Natomiast opowiadanie Czarne tabędzie (Чёрные лебеди, 1930) bezpośrednio nawiązuje do studium Lwa Szestowa Na szalach Hioba (На весах Иова, 1929). Jego główny bohater, niejaki Pawłow, podaje narratorowi konkretną datę swego samobójstwa i — nie zważając na jego protesty - spełnia to przyrzeczenie. Akcja opowiadania rozgrywa się w środowisku rosyjskich emigrantów i — jak zwykle u Gazdanowa — w Paryżu. Szkicuje on galerię typów ludzkich, przypominających postaci Dostojewskiego, przeniesione sprzed wieku w absolutnie obcy im świat. Pawłow, wkrótce samobójca, zapytany o Dostojewskiego, nazywa tego pisarza „łajdakiem”. Ten krytycyzm wobec autora Notatek z podziemia zdaniem niektórych został przejęty właśnie od Szestowa ${ }^{18}$.

\section{${ }^{14}$ Ibidem, s. 358}

15 Ibidem, s. 359.

16 Zob. К. А. Сундукова, Смерть, память и возвращение в романах Гайто Газданова, [w:] Мортальность в литературе и культуре, red. А. Г. Степанов, В. Ю. Лебедев, Москва 2015, s. 220-230.

17 Г. Газданов, Железный лорд..., s. 369.

18 Zob. C. А. Кибальник, Рассказ Гайто Газданова „Чёрные лебеди” как метатекст, „Вести Волгоградского государственного университета, сер. 8, Литературоведение. Журналистика" 2008, nr 7, s. 28-33. 
Uczyniwszy swym protagonistą jednego z „biednych ludzi” spośród emigracyjnej inteligencji, Gazdanow pokazuje, że zwykle odbierają sobie oni życie nie ze względów ideowych, lecz wskutek braku więzi międzyludzkich i totalnego zobojętnienia: „В Бога я не верю — powiada Pawłow - ни одной женщины не люблю. Жить мне скучно: работать и есть? Меня не интересует ни политика, ни искусство, ни судьба России, ни любовь"19.

Bohater Czarnych łabędzi przypomina petersburskich „marzycieli” wczesnego Dostojewskiego, choć nie jest ich kopią. Ciężko haruje w fabryce, ale w końcu rzuca pracę, by oddawać się rozmyślaniom: „Я узнал, что Павлов этот непоколебимый и непогрешимый человек, был, в сущности, мечтателем" 20 . Skrajności charakteru Pawłowa, w pewnym sensie rozdwojonego wewnętrznie dziwaka, takie jak stuprocentowa uczciwość obecnie i złodziejstwo niegdyś, sceptycyzm wobec wykształcenia uniwersyteckiego i uczęszczanie na studia w tajemnicy, wspomaganie bliźnich pieniędzmi w potrzebie i okazywany im chłód, egocentryzm, cynizm, zadowolenie, że „всё-таки на свете много дураков” "21, odmowa wzięcia pieniędzy od Swistunowa (,мне не нравится ваша услужливость” 22 , szczere do bólu „Вы мне не нужны” 23 w odpowiedzi na propozycję zamieszkania z nim kobiety - wszystko to sytuuje tę postać wśród rozdartych psychicznie, nieznajdujących dla siebie nigdzie miejsca bohaterów Dostojewskiego. Zamierzając odebrać sobie życie, Pawłow oznajmia narratorowi, że wybiera się do Australii; tę samą wiadomość przekazał matce — a to już bezpośrednie nawiązanie do autora Zbrodni i kary: wszak Swidrigajłow zwierzał się, że pojedzie do Ameryki, i okazało się, że ową Ameryką jest tamten świat.

Jak wiadomo, w twórczości autora Biesów można wskazać mnóstwo samobójców - ich typologię stworzyła i przebadała polska slawistka Mirosława Michalska-Suchanek w erudycyjnym studium Samobójcy Fiodora Dostojewskiego ${ }^{24}$. Analiza komparatystyczna samobójców Dostojewskiego i Gazdanowa bez wątpienia potwierdzi podobieństwa między nimi.

Pawłow z opowiadania Czarne łabędzie odbiera sobie życie, nie widząc jego sensu: „Дальнейшего смысла так же продолжать есть и работать, как сейчас, я не вижу" ${ }^{25}$. Interlokutor przekonuje go o bezcelowości podobnych myśli, co jest bliskie refleksji Szestowa. Pawłow jednak mu nie wierzy. Nazajutrz policja znajduje jego ciało w Lasku Bulońskim. Samobójstwo to trudno racjonalnie wyjaśnić. Nie jest jednak tragedią — wręcz przeciwnie. Słowa Pawłowa: „В сущности, я уезжаю в Австралию” 26 przypominają archetyp, zgodnie z którym śmierć sta-

\footnotetext{
19 Г. Газданов, Чёрные лебеди, [w:] idem, Собрание сочинений в трёх томах, s. 139.

20 Ibidem, s. 134.

${ }^{21}$ Ibidem, s. 135.

22 Ibidem, s. 137.

${ }^{23}$ Ibidem, s. 138.

24 M. Michalska-Suchanek, Samobójcy Fiodora Dostojewskiego, Katowice 2015.

${ }^{25}$ Ibidem, s. 127.

${ }^{26}$ Ibidem, s. 142.
} 
je się niekiedy podróżą do innego, lepszego życia (by wskazać tu chociażby finał Mistrza i Małgorzaty Bułhakowa). „Австралия была единственной иллюзией этого человека - mówi narrator - Она соединила в себе все желания, которые когда-либо у него появились, все его мечты и надежды"27. U Gazdanowa, podobnie jak u Szestowa, śmierć przynosi nadzieję. Pierwsza część książki Szestowa Na szalach Hioba, poświęconej Dostojewskiemu, zaczyna się i kończy słowami Eurypidesa, w których Szestow upatruje sens wszystkich dzieł Dostojewskiego: „Кто знает, - может, жизнь есть смерть, а смерть есть жизнь”.

Jedyną pasją Pawłowa były tytułowe czarne łabędzie: „он казался явно взволнованным, когда заговорил о лебедях, которых назвал самыми прекрасными птицами в мире. Знаете ли вы, - сказал он затем, - что в Австралии водятся чёрные лебеди?" 28 . Zdaniem badaczy stanowią one metaforę poezji, Pawłow mówi o nich przecież jako o poetyckim marzeniu swego życia. Pamięć o czarnych łabędziach (czyli o wysokiej poezji) powinna, według Gazdanowa, towarzyszyć człowiekowi zawsze.

W opowiadaniu Czarne tabędzie ma zatem miejsce apoteoza samobójczej śmierci, a obraz rzeczywistości, jaką rysuje jego autor, jest na wskroś tragiczny rosyjscy emigranci mogą uciec wyłącznie do owej metaforycznej Australii bądź Ameryki Dostojewskiego, znaleźli się w ślepym zaułku bez nadziei na choćby odrobinę lepszy los. Ich wyobcowanie jest dwojakie: etnokulturowe i egzystencjalne. Sam Gazdanow podzielał pod tym względem poglądy Lwa Szestowa.

\section{Bibliografia}

Бердяев Н. А., О самоубийстве (Психологический этюд), [w:] А. Н. Моховиков, Суицидология. Прошлое и настоящее. Проблема самоубийства в трудах философов, соииологов, психотерапевтов и в художественных текстах, Москва 2013.

Газданов Г., Собрание сочинений в трёх томах. Рассказы на франиузской земле, Москва 1996.

Демидова О. Р., Метаморфозы в изгнании. Литературный быт русского зарубежья, Санкт-Петербург 2003.

Закуренко А. Ю., Три лика смерти в романах Газданова, „Русская словесность” 2002, nr 4.

Кибальник С. А., Рассказ Гайто Газданова „Чёрные лебеди” как метатекст, „Вести Волгоградского государственного университета, Сер. 8, Литературоведение. Журналистика" 2008, nr 7.

Красильников Р. Л., Танатологические мотивы в художественной литературе (Введение в литературоведческую танатологию), Москва 2015.

Мокрова М. В., Танатология Г. Газданова и Б. Поплавского, [w:] Актуальные проблемь общественных наук и творческих профессий (философия, история, сочииологи, культура, искусство, религия), red. В. К. Крючек, Волгоград 2005.

Матвеева Ю.В., Экзистенциальное начало в творчестве Гайто Газданова, „Дарьял — литературно-художественный и общественно-политический журнал” 2001, nr 2.

27 Ibidem, s. 141-142.

28 Ibidem, s. 141. 
Моховиков А. Н., Суицидология. Прошлое и настоящее. Проблема самоубийства в трудах философов, социологов, психотерапевтов и в художественных текстах, Москва 2013.

Проскурина Е. Н., Танатологический сюжетно-мотивный комплекс в романной прозе Г. Газданова, „Критика и семиотика” 2013, nr 2.

Поплавский Б., О мистической атмосфере молодой литературы в эмиграции, „Числа” 1930, nr 2/3, s. 309.

Сундукова К. А., Смерть, память и возвращение в романах Гайто Газданова, [w:] Мортальность в литературе и культуре, red. А. Г. Степанов, В. Ю. Лебедев, Москва 2015.

Шабурова М. Н., Тема смерти в ранних рассказах Газданова, [w:] Возвращение, Гайто Газданова, Науч. конф. посвящ. 95-летию со дня рождения (4-5 дек. 1998), wyb. М. А. Васильева, Москва 2000.

Dienes L., Russian Literature in Exile. The Life and Work of Gaito Gazdanov, München 1982.

Michalska-Suchanek M., Samobójcy Fiodora Dostojewskiego, Katowice 2015.

\section{Suicide in Gaito Gazdanov's fiction}

Summary

Gaito Gazdanov, who was a representative of the young generation of Russian first-wave émigré writers, in his fiction shows particular interest in thanatology, especially suicides. Nikolai Berdyaev and Lev Shestov were recognized theoreticians in this field. In his short stories The Great Musician and Iron Lord Gazdanov argues with Berdyaev's ideas. Conversely, Black Swan corresponds with Shestov's views that suicide is a positive act and recalls the archetype depicting suicide as a journey into another, better life.

Keywords: Gaito Gazdanov, thanatology, suicide, Nikolai Berdyaev, Lev Shestov

\section{Суицид в творчестве Гайто Газданова}

\section{Резюме}

Гайто Газданова, писателя молодого поколения русских эмигрантов первой волны, отличает особенная заинтересованность проблемами танаталогии, в том числе суицидами. Известными теоретиками в этой области были Николай Бердяев и Лев Шестов. Гайто Газданов в рассказе Великий музыкант и особенно в рассказе Железный лорд полемизирует с концепциями Н. Бердяева. В свою очередь рассказ Чёрные лебеди перекликается со взглядами Льва Шестова, согласно которому самоубийство является положительным актом и напоминает архетип, представляющий самоубийство как путешествие в иную, лучшую жизнь. Шестов

Ключевые слова: Гайто Газданов, танатология, суицидология, Николай Бердяев, Лев 